\title{
O dever fundamental de obedecer às leis e a Desobediência Civil: uma análise do Artigo 33 da Declaração Americana dos Direitos e Deveres do Homem
}

\author{
The fundamental duty do obey laws and \\ Civil Disobedience: an Analysis of Article 33 of \\ the American Declaration of the Rights and Du- \\ ties of Man
}

\author{
Anselmo Laghi Laranja ${ }^{1}$ \\ Daury Cesar Fabriz²
}

Resumo: O presente artigo tem como objeto de pesquisa as teorias que fundamentam a desobediência civil.

1 Possui graduação em Direito pela Faculdade de Direito de Colatina (1990) e mestrado em História pela Universidade Federal do Espírito Santo (2005). Doutor em Direito e Garantias Fundamentais pela Faculdade de Direito de Vitória. Atualmente é professor da Faculdade Novo Milênio e juiz de direito - Tribunal de Justiça do Estado do Espírito Santo. E-mail: anselmolaranja@ gmail.com

2 Possui graduação em Direito pelo Centro Superior de Ciências Sociais de Vila Velha (1988), graduação em Ciências Sociais pela Universidade Federal do Espírito Santo (1994), mestrado em Direito pela Universidade Federal de Minas Gerais (1998) e doutorado em Direito pela Universidade Federal de Minas Gerais (2001). Atualmente é advogado - Fabriz, Ulhoa \& Advogados Associados, presidente da Academia Brasileira de Direitos Humanos, professor doutor nível I da Faculdade de Direito de Vitória e professor associado III da Universidade Federal do Espírito Santo. E-mail: daury@terra.com.br 
A partir do método de revisão de literatura, legislação e jurisprudência, objetiva-se avaliar as teorias que fundamentam a desobediência civil e o impacto do dever fundamental de obedecer às leis, presente no art. 33 da Declaração Americana dos Direitos e Deveres do Homem, para a reformulação delas. Como conclusão, defende-se a hipótese de que o processo de internacionalização dos direitos humanos permite uma nova fundamentação do caráter jurídico do fenômeno de desobediência civil naqueles casos em que houver uma contradição entre a declaração de constitucionalidade de uma norma pelo Supremo Tribunal Federal seguida pela declaração de inconvencionalidade da mesma norma pela Corte Interamericana de Direitos Humanos.

Palavras-chave: dever fundamental; desobediência civil; declaração americana de direitos e deveres do homem; internacionalização do direito.

Abstract: This article has the theories underlying civil disobedience as object of research. From the method of literature, legislation and jurisprudence review, the objective is to assess theories underlying civil disobedience and the impact of the fundamental duty to obey laws, as laid down in article 33 of the American Declaration of the Rights and Duties of Man, in order to reformulate them. As a conclusion, it is argued that the hypothesis that the process of internationalization of human rights allows a new reasoning of the legal character of civil disobedience in cases in which a contradiction is found between the declaration of constitutionality of a norm by the Federal Supreme Court followed by declaration of non-conventionalism of the same norm by the Inter-American Court of $\mathrm{Hu}$ man Rights. 
Key words: core duty; civil disobedience; American Declaration of the Rights and Duties of Man; internationalization of the law.

\section{INTRODUÇÃO}

A desobediência civil foi instrumento político relevante em diversos casos de luta por reconhecimento de direitos. $\mathrm{O}$ caso da campanha antiescravagista de Henry Thoreau nos Estados Unidos e a independência da Índia, com Mahatma Gandhi, são alguns dos exemplos privilegiados da utilização dessa estratégia política nos sécs. XIX e XX.

Todavia, a desobediência civil é um fenômeno bem mais antigo, como retratado na peça “Antígona" de Sófocles. De forma similar, a revolta era vista, no Código de Hamurabi, como castigo ao governante que não respeitava as leis (LUCAS, 2013, p. 25).

Todos os exemplos apresentados demonstram que a desobediência civil ou resistência a normas injustas é fenômeno comum em diversos períodos históricos. Essa perenidade, além demonstrar a relevância do tema, mantém o direito de resistência e a desobediência civil como fenômenos de análise contínua, em que o contexto histórico e cultural afetam a concepção que se tem deles.

Além do fato de ser condicionada ao contexto histórico e cultural, outra questão que envolve o tema da desobediência civil é o problema da subjetividade. A análise política desse fenômeno tem considerado a desobediência como um ato de oposição pública a uma parcela do ordenamento jurídico por falta de compatibilidade entre os valores professados pela autoridade pública e o cidadão. Em outras palavras, a desobediência é fruto da falta de legitimidade de determinada norma jurídica. 
O problema dessa perspectiva está na dificuldade de se aferir quando se trata de um ato legítimo de defesa a uma determinada concepção moral ou um mero interesse de grupos minoritários que buscam fazer sua vontade mesmo quando vencidos no processo legislativo formal.

Por essa razão, as teorias que fundamentam a desobediência civil tem buscado encontrar parâmetros legais para diminuir o grau de subjetividade desse fenômeno. Assim sendo, busca-se reduzir a subjetividade que a questão da legitimidade de determinada norma gera por uma noção de legalidade. Em resumo, pode-se dizer que há um esforço em determinar um tópoi ${ }^{3}$ de argumentação para a avaliação dos atos de desobediência e distinção desse fenômeno dos meros atos ilícitos.

No presente artigo, busca-se contribuir com esse esforço de buscar parâmetros intersubjetivos de fundamentação da desobediência civil e essa tentativa se utiliza do método de revisão de literatura, jurisprudência e legislação para enquadrar a desobediência civil no atual estágio de internacionalização do direito.

Em relação à esse processo de internacionalização, enfatiza-se a relação da desobediência com o sistema interamericano de direitos humanos. Essa ênfase justifica-se porque, ao mesmo tempo em que os Estados do continente americano possuem o mais antigo sistema internacional de proteção a direitos humanos do mundo, a Carta Política que o inaugurou, a Declaração Americana dos Direitos e

3 A construção jurídica enquanto buscar por motivos racionais baseados em concepções comuns aos diversos agentes sociais (topoi) foi introduzida por Theodor Viehwig (1979) baseado nos ensinamentos de Aristóteles. Para o referido autor, "Topoi são [...] para Aristóteles, pontos de vista utilizáveis e aceitáveis em toda parte, que se empregam a favor ou contra o que é conforme a opinião aceita e que podem conduzir à verdade" (VIEHWEG, 1979, p. 26-27). 
Deveres do Homens (1948), explicitou o dever humano de obediência à lei da seguinte forma: "Toda pessoa tem o dever de obedecer à Lei e aos demais mandamentos legítimos das autoridades do país onde se encontrar".

Nesse contexto, objetiva-se responder ao seguinte problema: como o dever fundamental de obediência à Lei, insculpido no art. 33 da Declaração Americana dos Direitos e Deveres do Homem, e as transformações geradas pela internacionalização do direito auxiliam na busca por critérios intersubjetivos para legitimar um ato de desobediência civil?

A construção de uma resposta a essa pergunta é feita em cinco capítulos. O primeiro busca distinguir a desobediência civil de seus fenômenos correlatos, como revolução e objeção de consciência. O segundo trata da trajetória histórica da desobediência civil. O terceiro cuida de analisar as teorias que fundamentam juridicamente a desobediência civil. O quarto apresenta as características principais do Sistema Interamericano de Direitos Humanos e o dever humano de obedecer às leis presente na Declaração Americana dos Direitos e Deveres do Homem. O quinto apresenta a distinção do controle de convencionalidade realizado pela Corte Interamericana de Direitos Humanos do controle de constitucionalidade realizado pelo Supremo Tribunal Federal. A título de conclusão, defende-se que é possível utilizar a Corte Interamericana de Direitos Humanos como parâmetro intersubjetivo de avaliação da legitimidade de um ato de desobediência civil.

\section{POR UMA COMPREENSÃO DE DESOBEDIÊN- CIA CIVIL}

Um dos fatores que geram a complexidade do estudo do tema da desobediência civil é a possibilidade de confusão 
com fenômenos similares, como a objeção de consciência e a revolução, bem como com um simples ato ilícito. $\mathrm{Na}$ verdade, parte dessa confusão decorre de perspectivas diferentes sobre cada um desses fenômenos. Por exemplo, Adverse (2012, p. 423) explica que a concepção professada por Hannah Arendt não considera que Sócrates e Thoreau são exemplos de desobediência civil, por não terem alcançado uma dimensão política. Portanto, num primeiro momento, cabe apresentar a concepção que se adotou neste artigo para a desobediência civil e os fenômenos correlatos, mesmo que se reconheça não ser essa a única classificação possível.

O ponto de partida será o chamado "direito de resistência", entendido enquanto ato de não cumprimento de determinada norma jurídica válida por não existir aceitação racional por parte de seus destinatários. Sob esse ponto de vista, concorda-se com Buzanello (2002, p. 135), quem considera que o direito de resistência é um termo genérico que abarca modalidades específicas: objeção de consciência, a desobediência civil e a revolução.

A objeção de consciência é uma forma de resistência lícita, autorizada pelo Estado em determinados casos em que, por questões filosóficas, políticas ou religiosas, o indivíduo considera imoral determinado dever (BUZANELLO, 2002, p. 141-142).

Walzer (1977, p. 105-106) trata de uma das causas mais comuns de objeção de consciência: a negativa de prestação de serviço militar obrigatório em decorrência de uma convicção pessoal. Esse caso também foi aceito pela Constituição Brasileira (BRASIL, 2014) no $\S 1^{\circ}$ do art. $143^{4}$. Para além dele,

4 Conforme texto constitucional: “Art. 143. O serviço militar é obrigatório nos termos da lei. $\S 1^{\circ}$ Às Forças Armadas compete, na forma da lei, atribuir serviço alternativo aos que, em tempo de paz, após alistados, alegarem imperativo de consciência, entendendo-se como tal o decorrente de crença religiosa e de convicção filosófica ou política, para se eximirem de atividades 
existem outros, como a objeção de consciência ao exercício profissional, ao tratamento médico, etc (BUZANELLO, 2002, p. 145-146).

A principal diferença entre a objeção de consciência e a desobediência civil é que a primeira possui uma fundamentação jurídica, enquanto a segunda não. Além disso, por ter causa jurídica, a objeção de consciência pode ser manifestada individualmente, sem necessidade de publicidade. Por seu turno, a desobediência civil exige uma certa "manifestação pública", o que lhe outorga caráter político.

Já a revolução pressupõe uma falta de legitimidade em todo o sistema jurídico. Sob a perspectiva democrática, é vista como ato politicamente legítimo quando se busca contrapor-se às tiranias (BUZANELLO, 2002, p. 155-156). Na revolução, há utilização de violência e transferência drástica de poder, de forma que é sempre considerada pelo regime antecessor como ato ilícito (BUZANELLO, 2002, p. 158).

A desobediência civil, assim como a revolução, é aberta, pública, mas não se utiliza de meios violentos (GARCIA, 2004, p. 269-270). Apesar disso, enquanto na revolução busca-se contrapor a todo o sistema jurídico vigente, na desobediência civil há resistência apenas em relação a determinados aspectos do ordenamento jurídico.

Na medida em que não é violenta, a desobediência civil não exime o desobediente da submissão à sanção. $\mathrm{O}$ comportamento de submissão à sanção, na verdade, reforça a legitimidade da desobediência. Conforme explica Santos e Lucas (2015, p. 194),

Os desobedientes aceitam a punição pelos seus atos como uma forma de chamar atenção da sociedade e criar as condições necessárias para a instauração do debate público. A punição é anuída como elemento estratégico, persuasivo, capaz de mobilizar a

de caráter essencialmente militar". 
opinião pública a adotar a mesma postura participativa e crítica assumida pelos desobedientes.

Sob a desobediência civil, Walzer (1977, p. 26) sustenta que se trata de situação em que há um conflito de legitimidades, pois há ausência de legitimidade em relação a uma determinada norma ou política estatal, mas não há perda de legitimidade quanto ao Estado/Direito como um todo. Walzer aponta, ainda, que na desobediência civil devem ser usados "métodos que não forcem ou oprimam diretamente outros membros da sociedade", bem como "a não-resistência a funcionários do estado quando executando a lei" (1977, p. 26).

No exemplo de sua utilização por Henry Thoreau (2012, p. 34) com o não pagamento de impostos para financiamento da Guerra do México no Séc. XIX, é dito:

Se este ano mil cidadãos deixarem de pagar seus impostos, essa medida não seria nem violenta nem cruel, ao contrário, seria cruel se fossem pagos, já que deste modo dão seu consentimento para que o Estado cometa atos de violência e derramamento de sangue inocente. Está é, de fato, a definição de uma revolução pacífica - se é que tal coisa é possível.

Portanto, é possível compreender a desobediência civil como um ato de resistência público, pacífico e parcial a uma ordem jurídica válida pela falta de aceitação racional de seu comando pelos destinatários. Em resumo, a desobediência civil é um ato ilícito, legítimo e não violento.

Uma vez compreendida a concepção que se adota de desobediência civil, pode-se adentrar na questão acerca da sua legalidade e de como ela tem sido aceita ou rejeitada enquanto um fenômeno jurídico a depender do contexto histórico e a teoria adotada. 


\section{A TRAJETORIA HISTÓRICA SOBRE O PROBLE- MA DA LEGALIDADE DA DESOBEDIÊNCIA CIVIL}

Uma vez compreendida a concepção que se adota de desobediência civil, pode-se adentrar ao problema da sua legalidade. Conforme visto, uma das características da desobediência civil é a ilicitude. Isso porque, como ilustra Carl Cohen (2013, p. 94), " A lei não pode justificar a violação da Lei". Essa observação transforma, por diversas vezes, a desobediência civil em um ato estritamente político, cujo sucesso dependerá exclusivamente da capacidade de mobilização do movimento social. Esse assunto, entretanto, é controverso.

Garcia (2004, p. 153) aponta que há pelo menos três perspectivas no que tange à relação entre resistência e direito: aqueles que consideram simplesmente como um direito moral e juridicamente ilícito; aqueles que consideram como um direito excepcional de caráter jurídico-filosófico; e aqueles que consideram não um direito, mas um estado de necessidade.

Sabe-se, também, que as diversas perspectivas entre resistência e direito possuem influência do contexto histórico em que são formadas. Na Idade Média, por exemplo, escritos de Santo Isidoro e Santo Tomás de Aquino influenciaram a concepção de que o dever de obediência ao poder real estaria sempre subordinado à legitimidade da autoridade, que correspondia a sua concordância com os princípios de bem comum da Igreja (LUCAS, 2013, p. 23-25).

Na modernidade, no entanto, a concepção jurídica dos atos de resistência enfraqueceu. Apesar de ter sido forte sua utilização nas revoluções burguesas, a pulverização do cristianismo com a Reforma Protestante e o fortalecimento dos Estados com estabelecimento das democracias repre- 
sentativas, gradualmente geraram o que João Maurício Adeodato (2002, p. 98) denomina de esvaziamento ético da modernidade.

Com a modernidade, não apenas o Estado-Nação tornou-se a última instância de poder, como também houve uma limitação do referencial moral comum e a construção da concepção de legitimidade enquanto procedimento.

A limitação do referencial moral comum tem como fator importante o gradual processo de reconhecimento da legitimidade da objeção de consciência iniciado por Martin Lutero. Isso gerou um gradual processo de individualização da fé (BUZANELLO, 2002, p. 9). Esse processo, para além de afetar a política, também afetou o direito, tendo jusnaturalismo ganhando contornos racionais.

Fruto da assunção do racionalismo moderno, o processo de codificação do direito marca o ápice do processo de secularização da autoridade. Como aponta Buzanello (2002, p. 81), "a racionalização do Estado se converte na estatização da razão, e a teoria da razão de Estado se torna outra face da teoria do Estado racional", assim como cria-se um cenário em que o "soberano determina o que é lícito e o que é ilícito, sem depender de nenhuma lei superior - não há matéria pré-constituída à lei positiva" (Buzanello, 2002, p. 81).

No mesmo sentido, boa parte das democracias modernas não conceberam a institucionalização (explícita) do direito à desobediência civil ou resistência, como é o caso da constituição brasileira. Garcia (2004, p. 167-168) sustenta que isso poderia ser explicado porque, uma vez que a promessa de um governo democrático foi alcançada, tornou-se difícil admitir a opressão num regime de divisão de poderes e representação popular. As ideologias modernas conceberiam a desobediência às leis democraticamente promulgadas como uma desobediência aos próprios valores democráticos. 
Observadas as variações que a concepção da relação entre resistência e direito possui em decorrência do contexto histórico, bem como demonstrado o fato de que, na modernidade, o direito de resistência ganhou contornos exclusivamente políticos em decorrência da configuração própria do direito, é possível contextualizar como as mudanças ocorridas na segunda metade do século XX alteraram esse quadro.

\section{A QUESTÃO DA LEGALIDADE DA DESOBEDI- ÊNCIA CIVIL NAS DEMOCRACIAS CONTEM- PORÂNEAS}

Após a Segunda Guerra Mundial, diversos países europeus passaram por profundas alterações em seu ordenamento jurídico, editando novas constituições de viés democrático, como a Alemanha (1949), Portugal (1976) e a Espanha (1978) (CARBONELL, 2005, p. 9). Além disso, o constitucionalismo ganhou contornos mundiais com a Carta da ONU e diversas declarações e convenções internacionais de direitos humanos (FERRAJOLI, 2005, p. 27).

Em seguida, a América do Sul (e em especial o Brasil) passou por seu processo de democratização. Nesse sentido, vale lembrar o apontamento de Piovesan $(2006$, p. 25) ao dizer que

No caso brasileiro, as relevantes transformações internas tiveram acentuada repercussão no plano internacional. Vale dizer, o equacionamento dos direitos humanos no âmbito da ordem jurídica interna serviu como medida de reforço para que a questão dos direitos humanos se impusesse como tema fundamental na agenda internacional do país. Por sua vez, as repercussões decorrentes dessa nova agenda internacional provocaram mudanças no plano interno e no próprio ordenamento jurídico do Estado brasileiro. [...] essas transformações têm gerado um novo constitucionalismo, 
bem como uma abertura à internacionalização da proteção dos direitos humanos.

Essas transformações políticas afetaram, também, a forma de se enxergar o fenômeno jurídico, principalmente por causa da regulamentação principialista destas normas. Como explica Sanchís (2009, p. 218), trata-se daqueles casos em que "se reconhecem direitos (e deveres correlatos) sem especificar suas possíveis colisões, nem as condições de precedência um sobre os outros" . Assim sendo, termos com alta carga axiológica e alto nível de vagueza ${ }^{5}$ foram adicionados aos textos constitucionais sem a existência de uma metodologia de trabalho para sua interpretação.

Conforme explica Wolkmer (1990, p. 34-35), “As doutrinas tradicionalmente legalistas e positivistas não admitem a violação da lei, nem tampouco aceitam a justificati-va [sic] jurídica de um ato de Desobediência Civil". Entretanto, as construções teóricas mais recentes acerca da legalidade da desobediência civil buscam nessa configuração axiológica das constituições contemporâneas um fundamento jurídico para a desobediência civil.

Essa concepção pode ser denominada desobediência civil enquanto "teste de constitucionalidade". É a perspectiva, por exemplo, de Canotilho (1993, p. 230) ao dizer que se trata de uma "desobediência à ordem conducente à prática de um crime".

Também Repolês (2003, p. 20) trata dessa concepção de desobediência civil ao dizer que:

Os desobedientes civis defendem os princípios constitucionais adotados na sociedade em que vivem e, com base nesses princípios, questionam a validade de um determinado preceito norma-

5 João Maurício Adeodato (2011, p. 272) conceitua vagueza como “a dúvida sobre os predicadores, ou seja, a que grupos de objetos determinada expressão se aplica, até o que (onde, quando, quem) alcança". 
tivo ou de uma determinada política governamental, alegando que esse preceito ou essa política, em última instância, não estão em conformidade com a Constituição.

Ainda entre os autores nacionais, Garcia (2004, p. 293-297) considera que se trata de um direito possibilitado pela abertura constitucional do art. $5^{\circ}, \S 2^{\circ}$ da Constituição Federal ${ }^{6}$, considerando-a uma proteção às prerrogativas inerentes à democracia.

Essa concepção de desobediência civil enquanto "teste de constitucionalidade", entretanto, é criticável. Carl Cohen (2013) explica isso a partir da diferenciação entre ações encorajadas e ações justificadas.

Quando existe uma ambiguidade no ordenamento jurídico ou existe uma norma que supostamente viola a Constituição, um ato de resistência ao comando inconstitucional é encorajado, mas não justificado.

Na medida em que canais institucionais de controle de constitucionalidade são acionados, haverá uma valoração da lei em relação à Constituição. Caso a norma seja realmente declarada constitucional, especialmente pela Corte Constitucional do Estado, considerar-se-á que não houve exercício regular de direito, mas uma desobediência clandestina. Já no caso da norma ser considerada inconstitucional, nunca terá havido desobediência, já que a norma inconstitucional nunca teve validade (COHEN, 2013, p. 96-97) e a conduta de resistência será entendida como exercício regular de direito.

Assim sendo, o "teste de constitucionalidade" não pode ser considerado ferramenta adequada para aferir a desobediência civil, já que a infração real à lei, e não a infração

6 Na forma descrita na Constituição (2014): "§2 $2^{\circ}$ Os direitos e garantias expressos nesta Constituição não excluem outros decorrentes do regime e dos princípios por ela adotados, ou dos tratados internacionais em que a República Federativa do Brasil seja parte". 
meramente aparente, é sua característica essencial (COHEN, 2013, p. 98).

A desobediência civil não pode ser tratada sem o aspecto apresentado por Repolês (2003, p. 20): quando a corte constitucional de determinado Estado considera que uma norma que está sendo alvo de desobediência civil pelos seus destinatários é constitucional e legítima ainda há espaço para se considerar a desobediência civil um ato legal?

Tendo em mente esse questionamento, pode-se passar a investigar a formação do sistema interamericano de direitos humanos e o dever de obedecer às leis insculpido no art. 33 da Declaração Americana de Direitos e Deveres do Homem.

\section{A FORMAÇÃO E DESENVOLVIMENTO DO SISTEMA INTERAMERICANO DE DIREITOS HUMANOS}

O sistema interamericano de direitos humanos surgiu em 1948, quando foi proclamada, pela IX Conferência Internacional Americana, a Carta da Organização dos Estados Americanos e a Declaração Americana de Direitos e Deveres do Homem, precedendo cronologicamente, inclusive, a Declaração Universal dos Direitos Humanos (BATISTA, 1999, p. 260).

Enquanto documento fundacional do sistema interamericano de direito humanos, a Declaração Americana foi proclamada sem natureza mandamental. Entretanto, como explica Cançado Trindade (1988, p. 14), no decorrer do percurso histórico ela ganhou relevância jurídica a medida em que serve de fonte para a formação da opinio juris, elemento que constitui o direito costumeiro que é fonte do direito internacional. 
A Declaração Americana é dividida na parte em que trata dos direitos (arts. 1 a 28) e na parte em que trata dos deveres (arts. 29 a 38). A existência de uma seção para a explicitação de deveres humanos não é um aspecto comum nas declarações internacionais, que, como explicam Tavares e Pedra (2014, p. 5-6), pode ser entendida pela forte tradição liberal ainda presente no mundo contemporâneo, o que gera uma supervalorização dos direitos frentes aos deveres.

Apesar disso, Sorto (2008, p. 19-20) aponta que a própria estrutura da Declaração já demonstra sua preocupação em apresentar os direitos e deveres humanos como aspectos indissociáveis de uma comunidade política plena.

Sob o ponto de vista teórico, deveres humanos podem ser entendidos a partir da conceituação de deveres fundamentais, compreendidos enquanto

uma categoria jurídico-constitucional [jurídico-convencional], fundada na solidariedade, que impõe condutas proporcionais àqueles submetidos a uma determinada ordem democrática, passíveis ou não de sanção, com a finalidade de promoção de direitos fundamentais (GONÇALVEZ, FABRIZ, 2013, p. 92).

Quando se observa o texto da Declaração Americana, percebe-se que este é capaz de retomar a questão da juridicidade da desobediência civil. Conforme estabelece o art. 33 do referido diploma internacional, "Toda pessoa tem o dever de obedecer à Lei e aos demais mandamentos legítimos das autoridades do país onde se encontrar".

Esse dispositivo, ao mesmo tempo em que cria um dever fundamental, condiciona-o a uma reserva de legitimidade para sua aplicação. Essa questão é pertinente porque, apesar de ter sido aprovado por unanimidade pelo Grupo de Trabalho que redigiu a declaração, esse dispositivo também foi evocado na discussão acerca do "direito de resistência" (COLOMBIA, 1953, p. 600). 
O "direito de resistência" foi discutido na IX Conferência Internacional Americana quando o representante da delegação da Guatemala justificou sua inclusão na Declaração Americana enquanto um direito correlato ao direito de acesso à justiça, naqueles casos em que houvesse recusa de apreciação de demandas ou evidente retardo nas demandas (COLOMBIA, 1953, p. 599).

A cláusula foi duramente criticada pelas delegações do Peru e da Argentina, que consideraram que ela poderia ser usada para justificar violações contra a democracia, baseadas em critérios subjetivos, já que não existiriam parâmetros de controle de sua utilização (COLOMBIA, 1953, p. 600-601).

Outro aspecto relevante é que a delegação dos Estados Unidos da América considerou, em um primeiro momento, que a cláusula do "direito de resistência" seria contrária ao dever de obediência às leis, mas, posteriormente, entendeu que eram artigos complementares, correlativos na dicotomia direito-dever (COLOMBIA, 1953, p. 600).

A cláusula não foi adicionada ao texto da Declaração Americana, mas a discussão no Grupo de Trabalho de redação desse diploma internacional demonstra como, por um lado, parte dos estados americanos reconheciam a resistência como um fenômeno legítimo e, por outro lado, temiam seu uso discricionário contra disposições democraticamente formuladas.

A questão da legitimidade das leis produzidas internamente foi retomada quando da promulgação da Convenção Americana sobre Direitos Humanos. Diferentemente da Declaração Americana, este dispositivo tem força mandamental e entrou em vigor em 1978. A ratificação pelo Brasil deste diploma ocorreu em 1992 (MAZZUOLI, 2011a, p. 882).

A importância da Convenção Americana não está apenas na promulgação de normas mandamentais para os 
Estados, mas também pela criação e consolidação de um conjunto de instituições capazes de julgar violações às suas disposições.

Tratam-se da Comissão e da Corte Interamericanas de Direitos Humanos. A primeira, criada desde 1959, teve suas competências ampliadas para poder ajuizar casos de violações de direitos humanos perante a Corte Interamericana, que, por sua vez, foi criada pela Convenção Americana e consiste em um tribunal supranacional para julgar essas supostas violações (PIOVESAN, 2006, p. 230-251).

A questão da legitimidade das leis internas foi retomada porque a Convenção estabelece dois tipos de obrigações para os Estados Parte. O primeiro é o dever dos Estados de respeitar os direitos dispostos na Convenção, que se consubstancia na obrigação de

organizar o poder público para garantir às pessoas sob sua jurisdição livre e pleno exercício dos direitos humanos. Isso se impõe independentemente dos responsáveis pelas violações desses direitos serem agentes do poder público, particulares, ou grupos desses, já que segundo as regras de Direito Internacional dos Direitos Humanos, a ação ou omissão de qualquer autoridade pública constitui um fato imputável ao Estado que compromete sua responsabilidade nos termos previstos pela mesma Convenção. (CORTE IDH, 2004, §210)

Assim, o Estado possui tanto um dever de natureza negativa, ou seja, não violar direitos humanos, quanto um dever de natureza positiva, que é o de adotar as medidas necessárias para a plena realização dos direitos humanos (PIOVESAN, 2006, p. 229).

Enquanto isso, o segundo tipo de dever consiste em adotar, no plano interno, uma legislação adequada para efetivar os direitos previstos na Convenção. Esse dever representa a obrigação tanto do Estado revogar qualquer norma ou suprimir qualquer prática que viole a Convenção, quanto 
a promulgação dos atos legislativos necessários para a efetivação das garantias nela disposta (CORTE IDH, 2006, §118).

Na forma transcrita na Convenção, é dito que:

Se o exercício dos direitos e liberdades mencionados no artigo 1 ainda não estiver garantido por disposições legislativas ou de outra natureza, os Estados-partes comprometem-se a adotar, de acordo com as suas normas constitucionais e com as disposições desta Convenção, as medidas legislativas ou de outra natureza que forem necessárias para tornar efetivos tais direitos e liberdades.

Um exemplo da utilização desse dispositivo pode ser visto no caso "Olmedo Bustos e outros vs. Chile" (CORTE $\mathrm{IDH}, 2001)$. Nele, a Corte Interamericana entendeu que o Chile violou o dever de revogar leis incompatíveis com a Convenção na medida em que manteve a censura cinematográfica em seu ordenamento, o que fez com que o filme "A Última Tentação de Cristo" fosse proibido de ser exibido no país. Quando a Corte realiza esse tipo de juízo sobre a legislação interna de um Estado, é dito que houve um controle de convencionalidade do ordenamento interno (SAGÜÉS, 2011, p. 273-274).

O caso merece destaque porque a censura cinematográfica estava disposta tanto no ordenamento infraconstitucional (Decreto Lei n. 679) quanto na própria constituição chilena (art. 19, n. 12). Isso demonstra que, no plano internacional, é considerado dever do Estado Parte não apenas reformar sua legislação ordinária, mas também realizar reformas constitucionais.

Apresentadas essas etapas do processo de internacionalização do direito e as obrigações contraídas pelos Estados Parte, pode-se demonstrar como a diferença da natureza jurídica desse controle de convencionalidade realizados pela corte internacional e pela corte interna pode criar um cenário que possa conceder legitimidade intersubjetivamente compartilhada à desobediência civil. 


\section{A DIFERENÇA NA NATUREZA DO CONTROLE DE CONVENCIONALIDADE INTERNO E IN- TERNACIONALE A FORMAÇÃO DE QUADRO DE LEGALIDADE DA DESOBEDIÊNCIA CIVIL}

Uma vez demonstrado que o processo de internacionalização do direito culminou em uma reserva de legitimidade para a exigência do dever de obedecer às leis, tal qual disposta pelo art. 33 da Declaração Americana de Direitos e Deveres do Homem e na submissão dos Estados Parte da Convenção Americana ao dever de adequar seu ordenamento jurídico interno às disposições da Convenção Americana sobre Direitos Humanos, pode ser demonstrado como esse processo permite um parâmetro intersubjetivo para avaliar a legitimidade de um ato desobediência civil.

O fundamento dessa tese está na diferença da natureza do controle de convencionalidade realizado pelas cortes internas e pelas cortes internacionais.

Conforme explica Guerra (2017, p. 8):

controle de convencionalidade [...] se apresenta como um mecanismo processual utilizado para averiguar se o direito interno [...] viola algum preceito estabelecido pela Convenção Interamericana sobre Direitos Humanos mediante um exame de confrontação normativo em um caso concreto.

Além de ser realizado em sede internacional, a Corte Interamericana tem construído uma jurisprudência no sentido de que não apenas ela deve realizar controle de convencionalidade das leis, mas também os órgãos jurisdicionais internos dos Estados Parte da Convenção Americana (CORTE IDH, 2010, §225; CORTE IDH, 2014a, §151; CORTE IDH, 2014b, §331). 
No caso brasileiro, Mazzuoli (2011b, p. 10) leciona que, a depender da situação, o Poder Judiciário pode tanto exercer controle de convencionalidade difuso quanto concentrado. No primeiro caso, a inconvencionalidade da lei é posta enquanto questão preliminar de determinada demanda e a decisão que acata o pedido considera a lei invalidada para o caso concreto (MAZZUOLI, 2011b, p. 152). Já no segundo caso, o controle de convencionalidade é realizado pelo Supremo Tribunal Federal, tal qual o controle de constitucionalidade, para questionar a validade em abstrato da lei (MAZZUOLI, 2011b, p. 151).

Em consonância com o controle de constitucionalidade, quando a inconvencionalidade é declarada pelo controle difuso, ela "não anula a lei nem a revoga; teoricamente, a lei continua em vigor, eficaz e aplicável" (SILVA, 2005, p. 53).

Por outro lado, o efeito jurídico do controle de convencionalidade por via concentrada no Poder Judiciário é a retirada da aplicabilidade desta norma, cujos efeitos da decisão são imediatos ao trânsito em julgado e vinculam todos os cidadãos e o poder público (SILVA, 2005, p. 54). Isso decorre do fato de que o Poder Judiciário é competente para interpretar o ordenamento jurídico interno.

Do ponto de vista internacional, o controle de convencionalidade tem o mesmo efeito que o controle de constitucionalidade difuso, já que avalia, em um caso concreto, se determinada norma é incompatível com a Convenção Americana (SAGÜÉ, 2011, p. 283). Assim, a norma perde a aplicabilidade naquele caso.

A primeira ressalva que precisa ser feita é que a Corte Interamericana não tem competência para revisar a interpretação dada pelo Poder Judiciário acerca de seu próprio ordenamento jurídico. Isso deve-se ao princípio da "vedação da fórmula da quarta instância", que compreende que a "os 
órgãos do Sistema Interamericano 'não podem revisar as sentenças proferidas pelos tribunais nacionais que atuam na esfera de sua competência e que aplicam as devidas garantias judiciais" (CORTE IDH, 2007, §19).

Tendo isso em vista, o controle de convencionalidade nunca é feito no sentido de corrigir a interpretação dada pelo Poder Judiciário, mas de considerar que o ordenamento interno, tal qual demonstrado pela intepretação do seu Poder Judiciário, é incompatível com a Convenção.

A segunda ressalva é que, quando se trata de interpretação de cláusulas constitucionais, a concepção de que a sentença da Corte Interamericana pode retirar sua aplicabilidade demanda a compreensão de que a Convenção Americana possui um status supraconstitucional. Entretanto, esse não é o entendimento brasileiro. Desde o julgamento do RE 466.343SP, que discutiu o impacto da Convenção Americana sobre Direitos Humanos no caso do depositário infiel, o Supremo Tribunal Federal considerou que os tratados internacionais de direitos humanos possuem dois status normativos para o direito brasileiro: constitucional, quando ratificados com o quórum do art. $5^{\mathrm{o}}, \S 3^{\mathrm{o}}$ instituído pela Emenda Constitucional n. 45/2004; supralegal e infraconstitucional, quando ratificados anteriormente a essa emenda (VEIRA; VEDONATO, 2015, p. 214-215).

No caso da Convenção Americana, estar-se-ia diante de um tratado que é supralegal e infraconstitucional, de forma que, para o Supremo Tribunal Federal, as normas constitucionais revogariam as disposições da Convenções.

7 Na forma transcrita na Constituição (BRASIL, 2014): “§ $3^{\circ}$ Os tratados e convenções internacionais sobre direitos humanos que forem aprovados, em cada Casa do Congresso Nacional, em dois turnos, por três quintos dos votos dos respectivos membros, serão equivalentes às emendas constitucionais". 
Por esses dois motivos, surge a possibilidade de existência de casos em que a norma, declarada constitucional pelo Supremo Tribunal Federal e inconvencional pela Corte Interamericana de Direitos Humanos, crie uma situação segundo a qual a lei é "lícita" para o Poder Judiciário, mas "ilegal" para a comunidade internacional, ou o contrário.

Essa situação já havia sido prevista por Kelsen (1998, p. 528). O teórico, que defendeu que o ordenamento jurídico interno e internacional são o mesmo (teoria monista), considerava que

O Direito internacional geralmente obriga um Estado a dar às suas normas certos conteúdos, no sentido de que, se o Estado decretar normas com outros conteúdos, estará sujeito a uma sanção internacional. Uma norma que, como se costuma dizer, é decretada em "violação" do Direito internacional geral permanece válida mesmo segundo o Direito internacional geral. O Direito internacional geral não estabelece nenhum processo pelo qual normas de Direito nacional que são "ilegais" (do ponto de vista do Direito internacional) possam ser abolidas.

Quando essa contradição de decisões entre a corte constitucional e a corte internacional é analisada no caso brasileiro, em que a Convenção Americana de Direitos Humanos possui status infraconstitucional, surge o cenário em que o Estado brasileiro mantém a coerência de seu ordenamento jurídico com base na prevalência da decisão interna, mas, para isso, viola acordos internacionais que foram por ele mesmo aceitos.

É com base nesses pressupostos que surge a possibilidade de superar o obstáculo gerado pelo risco de uso indiscriminado da desobediência civil em sociedades democráticas ao mesmo tempo em que se resolve o problema dos efeitos da jurisdição constitucional nesses casos. $\mathrm{O}$ peculiar relacionamento entre direito interno e internacional, nesses casos, faz surgir um parâmetro intersubjetivo (topói) 
previamente aceito por ambos os lados em conflito (Estado e desobediente) para se legitimar o ato de desobediência.

Conforme visto, nas assembleias da IX Conferência Internacional Americana, foi discutido que o dever de obedecer às leis legítimas possui correlação com o direito de resistir àquelas violações à justiça.

Por outro lado, o receio que uma cláusula que reconhecesse o direito de resistência fosse usada para violar a democracia impediu, em 1948, a explicitação desse direito e a principal razão para esse temor foi a subjetividade do julgamento acerca de quando um ato é violação à justiça.

A medida em que o processo de internacionalização do direito e o sistema interamericano de direitos humanos foram se desenvolvendo, a questão da compatibilidade das leis internas com os direitos humanos reconhecidos internacionalmente voltou a ser regrada, mas por meio de um sistema que prevê sanções aos Estados Parte que descumprirem esse dever de compatibilidade.

Caso se reconhecesse que a Convenção Americana possui status supraconstitucional e, assim, capaz de revogar disposições constitucionais, ter-se-ia novamente o problema da desobediência civil enquanto um "teste de constitucionalidade", mas alterando a esfera última de julgamento e tornando esse teste em um "teste de convencionalidade".

Apesar disso, o posicionamento brasileiro de considerar que a Convenção Americana tem status infraconstitucional criou situação em que a desobediência à lei declarada constitucional pelo Supremo Tribunal Federal, mas inconvencional pela Corte Interamericana, é um ato ilícito, mas legítimo conforme os valores pactuados pelo próprio Estado brasileiro na comunidade internacional. Frisa-se, ainda, que, nesse cenário, a legitimidade da conduta "ilícita" não depende de critérios subjetivos do infrator, mas do julgamento técnico 
de um corpo de juristas.

Assim sendo, vislumbra-se que todo o processo de internacionalização apresentado culminou na possibilidade de formulação da tese segundo a qual, para esses casos, a desobediência civil (a resistência ao cumprimento da lei interna), mantendo sua característica de ilicitude, consegue alcançar um critério intersubjetivo de legitimidade capaz de diferenciar aqueles atos de mera infração da lei com aqueles voltados à resguardar direitos fundamentais.

\section{CONSIDERAÇÕES FINAIS}

O processo de internacionalização do direito gerou não apenas a existência de deveres para os Estados nacionais em plano internacional, mas também institucionalizou mecanismos de cobrança dessas obrigações. Como exemplo desses mecanismos, as cortes internacionais, em especial a Corte Interamericana de Direitos Humanos, passaram a poder julgar condutas de Estados que, no início da Modernidade, eram vistos como fontes últimas de poder e legitimidade.

Uma das obrigações que os estados americanos assumiram ao aderir ao sistema interamericano de proteção dos direitos humanos foi o dever de adotar disposições de direito interno compatíveis com a Convenção Americana de Direitos Humanos, na forma do seu artigo $2^{\circ}$.

Assim, a natureza do processo e julgamento pela condenação dos Estados nacionais pelo descumprimento do dever de adotar disposição interna compatível com a Convenção Americana é diferente das decisões tomadas pelo Supremo Tribunal Federal, mesmo quando em sede de controle de convencionalidade.

Tanto no controle de constitucionalidade quanto no controle de convencionalidade, o Supremo Tribunal Federal 
declara a inconstitucionalidade/inconvencionalidade de determinado ato normativo, retirando a validade do dispositivo normativo em julgamento.

Por outro lado, a Corte Interamericana não possui essa prerrogativa, criando situação em que a condenação em plano internacional se torna o reconhecimento que existe norma válida no plano interno de determinado Estado nacional que viola direitos humanos, bem como obriga o Estado a adotar medidas de alteração legislativa.

Apesar dessa limitação da jurisdição internacional, uma decisão contrária ao ordenamento jurídico interno auxilia na formação da fundamentação racional baseada em acordo comum entre as partes em conflito em um caso de desobediência civil. A medida que a Corte tem a prerrogativa de interpretar as obrigações que os Estados Nacionais assumiram com a ratificação da Convenção Americana, elas também podem ser utilizadas como critério intersubjetivo para fundamentar a desobediência civil (verdadeiros topói), tornando-se claro que o ato de resistência não consiste em mero interesse de grupos minoritários.

Sob essa perspectiva, a desobediência civil pode fundamentar intersubjetivamente sua legitimidade nesses contextos em que o Supremo Tribunal Federal declarou a constitucionalidade de determinada norma, mas o sistema interamericano de direitos humanos, apesar de não poder revisar as interpretações das cortes internas, condena o Estado a alterá-la por força da disposição do art. $2^{\circ}$ da Convenção Americana de Direitos Humanos.

Assim considerada, a desobediência civil à norma declarada violadora de direitos humanos pela Corte Interamericana, mas declarada constitucional pelo STF possui, se somada a não violência, todos os elementos essenciais da desobediência civil no plano político (ilicitude, legitimidade 
e não violência) ao mesmo tempo que conta com órgãos institucionais e procedimentos previamente aceitos pelo Estado (brasileiro) para eliminar a subjetividade do fenômeno.

Essa hipótese fundamenta a resposta dada ao problema de pesquisa que orienta esse artigo. Por outro lado, ela abre margem para novas problematizações. Por exemplo, é possível se perguntar se a hipótese formulada se aplica apenas em realidades como a brasileira, cujo Estado Nacional reconhece que os tratados internacionais de direitos humanos têm natureza infraconstitucional, ou pode ser aplicada em outras situações.

No mesmo sentido, abre-se margem para problematizar se apenas decisões das cortes internacionais teria esse condão de ser um parâmetro intersubjetivo para a desobediência civil, ou relatórios e manifestações de outros órgãos também seria capaz de atribuir essa legitimidade.

De qualquer forma, os resultados alcançados no presente artigo permitem entender que a relação entre o ordenamento jurídico interno e a legislação internacional de proteção a direitos humanos é um objeto de pesquisa pertinente para o contínuo estudo do fenômeno da desobediência civil.

\section{Referências bibliográficas}

ADEODATO, João Maurício. Ética e retórica: para uma teoria da dogmática jurídica. São Paulo: Saraiva, 2002.

ADEODATO, João Maurício. Uma teoria retórica da norma jurídica e do direito subjetivo. São Paulo: Noeses, 2011.

ADVERSE, Holton. Arendt, a democracia e a desobediência civil. Revista Brasileira de Estudos Políticos, Belo Horizonte, n. 105, pp. 409-434, jul.dez., 2012.

BATISTA, Vanessa Oliveira. As declarações de direitos. 
Revista da Faculdade de Direito da Universidade Federal de Minas Gerais, Belo Horizonte, n. 36, pp. 251-267, 1999. BUZANELLO, José Carlos. Direito de resistência constitucional. Rio de Janeiro: América Jurídica, 2002.

BRASIL. Constituição (1988). Constituição da República Federativa do Brasil. 41 ed. Brasília: Câmara dos Deputados, Edições Câmara, 2014.

CANÇADO TRINDADE, Antônio Augusto. Reflexões sobre o valor jurídico das Declarações Universal e Americana de Direitos Humanos de 1948 por ocasião de seu quadragésimo aniversário. Revista de Informação Legislativa, Brasília, a. 25, n. 99, jul./set. 1988.

CANOTILHO, Joaquim Gomes. Direito constitucional. 6. ed. Coimbra: Editora Almedina, 1993.

CARBONELL, Miguel. Neoconstitucionalismo(s). 2. ed. Madrid: Editorial Trotta, 2005.

COHEN, Carl. Civil desobedience: conscience, tactics, and the law. MPublishing: AnnArbor, 2013.

COLOMBIA. Ministerio de Relaciones Exteriores de Colombia. Actas y documentos. Novena Conferencia Internacional Americana, Bogotá: Ministério de Relaciones Exteriores de Colombia, 1953.

CORTE IDH. Corte Interamericana de Direitos Humanos. Caso "A Última Tentação de Cristo" (Olmedo Bustos e outros) vs. Chile. Mérito, Reparações e Custas. Série C No. 73. 5 fev. 2001.

CORTE IDH. Corte Interamericana de Direitos Humanos. Caso 19 comerciantes vs. Colombia. Mérito, Reparações e Custas. Serie C No. 109. 5 jul. 2004. 
CORTE IDH. Corte Interamericana de Direitos Humanos. Caso Almonacid Arellano e outros vs. Chile. Exceções Preliminares, Mérito, Reparações e Custas. Série C No. 154. 26 set. 2006.

CORTE IDH. Corte Interamericana de Direitos Humanos. Caso Cabrera García e Montiel Flores vs. México. Exceções Preliminares, Mérito, Reparações e custas. Seri C No. 220. 26 nov. 2010.

CORTE IDH. Corte Interamericana de Direitos Humanos. Caso Chaparro Álvarez y Lapo Íñiguez vs. Ecuador. Exceções Preliminares, Mérito, Reparações e Custas. Série C No. 172. 28 nov. 2007.

CORTE IDH. Corte Interamericana de Direitos Humanos. Caso de pessoas dominicanas e haitianas expulsadas. Exceções Preliminares, Mérito, Reparações e Custas. Serie C No. 282. 28 ago. 2014a.

CORTE IDH. Corte Interamericana de Direitos Humanos. Caso Liakat Ali Alibux vs. Suriname. Exceções Preliminares, Reparações, Mérito e Custas. Serie C No. 276. 30 jan. 2014b.

FERRAJOLI, Luigi. Pasado y futuro del Estado de Derecho. In.: CARBONELL, Miguel. Neoconstitucionalismo(s). 2. ed. Madrid: Editorial Trotta, 2005.

GARCIA, Maria. Desobediência civil: direito fundamental. 2. ed. São Paulo: Editora Revista dos Tribunais, 2004.

GONÇALVES, Luísa Cortat Simonetti; FABRIZ, Daury César. Dever fundamental: a construção de um conceito. In: MARCO, Christian Magnus De; PEZZELLA, Maria Cristina Cereser; STEINMETZ, Wilson. Teoria geral e mecanismos de efetividade no Brasil e na Espanha. 1. t. Joaçaba: Editora Unoesc, 2013. 
GUERRA, Sidney. Controle de convencionalidade. Revista Jurídica, Curitiba, v. 1, n. 46, pp. 1-21, 2017.

HABERMAS, Jürgen. Facticidad y validez: sobre el derecho y el Estado democrático de derecho em términos de teoria del discurso. 6. ed. Madrid: Editorial Trotta, 2010.

KELSEN, Hans. Teoria geral do direito e do estado. 3. ed. São Paulo: Martins Fontes, 1998.

LUCAS, Doglas Cesar. Direito de resistência e desobediência civil: história e justificativas. Revista Direito em Debate, v. 8, n. 13, 2013.

MAZZUOLI, Valerio de Oliveira. Curso de direito internacional público. 5. ed. São Paulo: Editora Revista dos Tribunais, 2011a.

MAZZUOLI, Valério de Oliveira. O controle jurisdicional da convencionalidade das leis. 2. ed. São Paulo: Editora Revista dos Tribunais, 2011b.

MOREIRA, Nelson Camatta. Direitos e garantias constitucionais e tratados internacionais de direitos humanos. Belo Horizonte: Fórum, 2012.

PIOVESAN, Flávia. Direitos humanos e o direito constitucional internacional. 7. ed. São Paulo: Saraiva, 2006.

REPOLÊS, María Fernanda Salcedo. Habermas e a desobediência civil. Belo Horizonte: Mandamentos, 2003.

SAGÜÉS, Néstor Pedro. Obligaciones internacionales y control de convencionalidad. Opus Magna, t. 4. 2011.

SANCHÍS, Luis Pietro. El constitucionalismo de los derechos. In.: CARBONELL, Miguel. Teoría del neoconstitucionalismo: ensayos escogidos. Madrid: Editorial Trotta, 2009.

SANTOS, André Leonardo Copetti; LUCAS, Doglas Cesar. Desobediência civil e controle social da democracia. Revista 
Brasileira de Estudos Políticos, Belo Horizonte, n. 110, pp. 179-215, jan./jun. 2015.

SILVA, José Afonso. Curso de direito constitucional positivo. 25. ed. São Paulo: Malheiros Editores, 2005.

SORTO, Fredys Orlando. A declaração universal dos direitos humanos no seu sexagésimo aniversário. In.: Verba Juris, a. 7, n. 7, jan./ dez., 2008.

TAVARES, Geovane de Oliveira. Desobediência civil e direito político de resistência: os novos direitos. Campinas: Edicamp, 2003.

TAVARES, Henrique da Cunha; PEDRA, Adriano Sant'Ana. A eficácia dos deveres fundamentais. In: Derecho y cambio social, n. 37, a. 11, Lima, 2014.

THOREAU, Henry David. Desobediência civil. Cidade do México: Tumbona Ediciones, 2012.

VIEHWEG, Theodor. Tópica e jurisprudência. Brasília: Unb Editora, 1979.

VIEIRA, Luciane Klein; VEDONATO, Luís Renato. A relação entre direito interno e direito internacional: os impactos no cotidiano jurídico brasileiro sob a perspectiva da ampliação do bloco de constitucionalidade. Revista de la Secretaría del Tribunal Permanente de Revisión, a. 3, n. 6, pp. 207225, ago. 2015.

WALZER, Michael. Das obrigações políticas: ensaios sobre desobediência, guerra e cidadania. Rio de Janeiro: Zahar Editores, 1977.

WEBER, Max. Economia e sociedade: fundamentos da sociologia compreensiva. Brasília: Editora Universidade de Brasília, 1999. 
WEBER, Max. Ensaios de sociologia. 5. ed. Rio de Janeiro: LTC Editora, 1982.

WOLKMER, Antonio Carlos. Desobediência civil nas sociedades democráticas. Sequência, Florianópolis, v. 11, n. 20, 1990.

Recebido em 02/01/2018.

Aprovado em 20/02/2018.

Anselmo Laghi Laranja

E-mail: anselmolaranja@gmail.com

Daury Cesar Fabriz

E-mail: daury@terra.com.br 
